\title{
Effect of Trust, Quality of Products and Quality Services on Purchase Decisions on E-Commerce Shopee in Palembang City

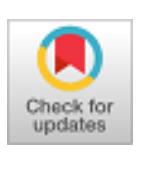

\author{
Andryusalfikri, Zakaria Wahab, Marlina Widiyanti,
}

Abstract: Purchasing decision is the decision of consumers to buy a product or service as desired. This study aims to determine the effect of trust, product quality and service quality on purchasing decisions at e-commerce Shopee in Palembang. This study uses multiple linear regression analysis. The sample in this study were 100 respondents who showed the results that the variables of trust, product quality and service quality had a positive and significant effect on purchasing decisions in e-commerce Shopee. there is one variable that has dominant influence on purchasing decisions, namely the variable trust in purchasing decisions

Keywords: Trust, Product Quality, Service Quality, Purchasing Decision

\section{I.INTRODUCTION}

In the current era of globalization, a lot of progress and changes have taken place in the modern business world such as the digital e-commerce business. The changes that occur are marked by the mindset of the developing community, technological advancements, and lifestyles that cannot be separated from the influence of globalization. With the progress and changes, indirectly it requires us to be able to compensate. The influence of the development of the era is that there are many emerging products and services that offer various advantages of products and services. This makes consumers have many alternative choices in choosing goods and services offered by producers.



Source: databoks.co.id

Figure 1.2.

E-Commerce with the Most Visitors in Indonesia in 2018

Based on Figure 1.2, there are 10 e-commerce with the highest number of visitors in Indonesia. In 2018 the highest is Lazada with 117.6 million visitors, Tokopedia as many as 117.3 million visitors, Bukalapak with 93.6 million visitors,

Revised Manuscript Received on August 14, 2019.

* Correspondence Author

Andryusalfikri*, Faculty of Economics, Master of Management, Sriwijaya University

Zakaria Wahab, Faculty of Economics, Master of Management, Sriwijaya University

Marlina Widiyanti, Faculty of Economics, Master of Management, Sriwijaya University

(C) The Authors. Published by Blue Eyes Intelligence Engineering and Sciences Publication (BEIESP). This is an open access article under the CC BY-NC-ND license (http://creativecommons.org/licenses/by-nc-nd/4.0/)
Blibli 45.9 million visitors, Shopee 34.5 million visitors to JD.id were 13.2 million visitors, Bhineka was 7.4 million visitors, Elevenia was 6.3 million visitors, Zalora was 5.2 million visitors and Matahari Mall was 4 million visitor. Based on the background above, encouraging researchers to conduct research with the title "Effect of Trust, Product Quality and Service Quality on Purchase Decisions in Shopee E-Commerce in Palembang City".

\section{II.LITERATURE REVIEW}

\section{A. Purchase Decision}

M According to Kotler (2012), purchasing decisions are a stage where consumers have a choice and are ready to make a purchase or exchange between money and promises to pay with ownership rights or use of an item or service.

\section{B. Trust}

According to Kotler and Keller (2012), trust is the willingness of companies to depend on business partners. Trust depends on several factors between individuals and between organizations such as competence, integrity, honesty and kindness. Building trust can be difficult in online situations, companies apply strict regulations to their online business partners compared to other partners. Business buyers worry that they will not get the right quality product or service delivered to the right place at the right time, and vice versa.

\section{Product Quality}

According to Kotler and Armstrong (2012: 283), product quality is the ability of a product to demonstrate its function and is one of the most reliable factors by a marketer in marketing a product. Therefore, improving the quality of products or services is an important challenge for companies to compete in the global market. Improving product quality will reduce costs and increase competitive advantage, even further, high product quality creates a long-standing competitive advantage. Therefore, quality is an important factor that drives the economic growth of companies anywhere in the world in the context of global markets.

\section{Service Quality}

Service quality is the customer's assessment of the superiority or privilege of a product or service as a whole (Zeithaml, 1990). Service quality must begin with customer needs and end with customer satisfaction and perception of service quality.

Published By:

Blue Eyes Intelligence Engineering

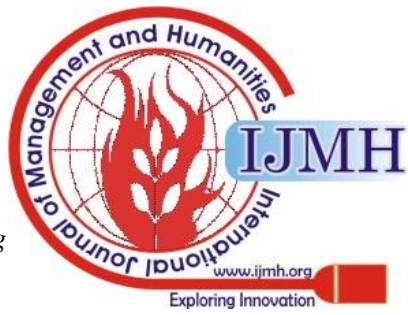


As a party that uses services, customers as assessors of the level of service quality of a company, one of the factors that determine the level of success and quality of the company in providing services to.

\section{E. Conceptual Framework for Thought}

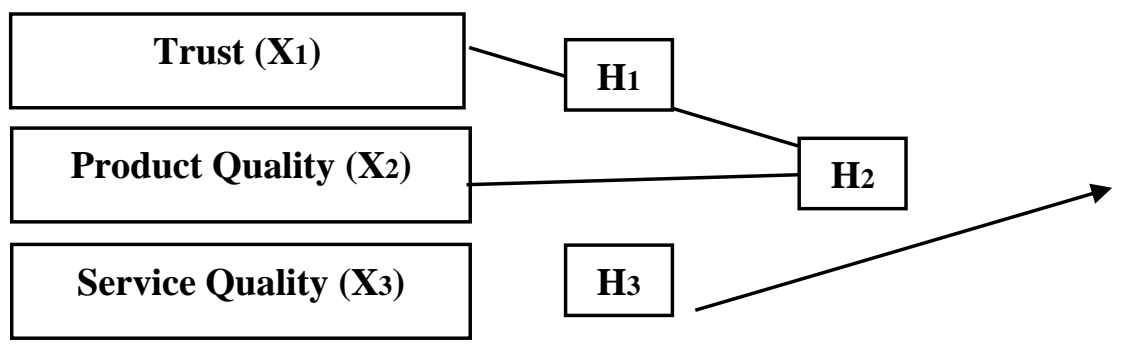

\section{Purchase Decision (Y)}

\section{Picture 2.1 Research Conceptual Framework}

\section{III.RESEARCH METHODS}

This study intends to measure the relationship between research variables. This study is useful for measuring the relationships between research variables or useful for analyzing and seeing the effect of independent variables (X) on the dependent variable (Y).

The design of this study is as follows:

1. Variable X (Free Variables), namely Trust, Product Quality and Service Quality

2. Variable Y (Bound Variable), namely the Purchase Decision
The sampling technique in this study used purposive sampling technique. Respondents in this study were part of Shopee e-commerce customers in Palembang. The criteria of respondents taken as samples were customers who had made purchases at e-commerce Shopee in the city of Palembang over the past five months as many as 100 respondents.

\section{A. Research Results \\ Validity test}

Table 4.9. Validity Test Results

\begin{tabular}{cccccc}
\hline Indicator & $\begin{array}{c}\text { Product Moment } \\
\text { Pearson's }\end{array}$ & Sig. & & A & Informatiaon \\
\hline X1.1 & 0,483 & 0,000 & $<$ & 0,05 & Valid \\
X1.2 & 0,633 & 0,000 & $<$ & 0,05 & Valid \\
X1.3 & 0,601 & 0,000 & $<$ & 0,05 & Valid \\
X1.4 & 0,572 & 0,000 & $<$ & 0,05 & Valid \\
X1.5 & 0,595 & 0,000 & $<$ & 0,05 & Valid \\
X2.1 & 0,578 & 0,000 & $<$ & 0,05 & Valid \\
X2.2 & 0,608 & 0,000 & $<$ & 0,05 & Valid \\
X2.3 & 0,546 & 0,000 & $<$ & 0,05 & Valid \\
X2.4 & 0,515 & 0,000 & $<$ & 0,05 & Valid \\
X2.5 & 0,627 & 0,000 & $<$ & 0,05 & Valid \\
X3.1 & 0,605 & 0,000 & $<$ & 0,05 & Valid \\
X3.2 & 0,552 & 0,000 & $<$ & 0,05 & Valid \\
X3.3 & 0,705 & 0,000 & $<$ & 0,05 & Valid \\
X3.4 & 0,526 & 0,000 & $<$ & 0,05 & Valid \\
X3.5 & 0,528 & 0,000 & $<$ & 0,05 & Valid \\
Y.1 & 0,538 & 0,000 & $<$ & 0,05 & Valid \\
Y.2 & 0,487 & 0,000 & $<$ & 0,05 & Valid \\
Y.3 & 0,586 & 0,000 & $<$ & 0,05 & Valid \\
Y.4 & 0,487 & 0,000 & $<$ & 0,05 & Valid \\
Y.5 & 0,477 & 0,000 & $<$ & 0,05 & Valid \\
\hline
\end{tabular}

2019 Data Source: Processed from Questionnaire, 2019

Based on Table 4.9, it is known that each indicator (item) in each variable of trust, product quality and service quality (independent variable) while purchasing decision (dependent variable) has the result of Product Moment Pearson's value with a significance value of $0,000<0,05$, so that the indicators (items) used in this research variable can be declared appropriate or relevant and can be used as items in data collection.

\section{Reliability Test}

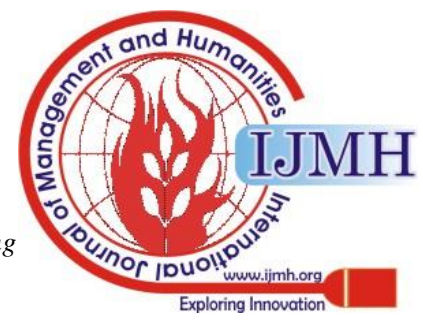


Effect of Trust, Quality of Products and Quality Services on Purchase Decisions on E-Commerce Shopee in Palembang City

Table 4.10. Research Variable Instrument Reliability Test Results

\begin{tabular}{lcccc}
\hline \multicolumn{1}{c}{ Variable } & $\begin{array}{c}\text { Cronbach's } \\
\text { Alpha }\end{array}$ & Cutt Off & N of Item & Information \\
\hline Trust (X1) & 0,721 & $>0,60$ & 10 & Reliable \\
Product Quality (X2) & 0,718 & $>0,60$ & 10 & Reliable \\
Service Quality (X3) & 0,724 & $>0,60$ & 10 & Reliable \\
Purchase Decision (Y) & 0,667 & $>0,60$ & 10 & Reliable \\
\hline
\end{tabular}

Source: Processed from Questionnaire, 2019

Based on the results of the instrument variable reliability test in Table 4.10, then from the results of the reliability test the independent variables of trust (X1), product quality (X2) and service quality (X3) indicate that the data obtained is reliable because Cronbach's Alpha value is $0.721,0.718,0.724$ while the reliability test results of the dependent variable purchasing decision $(\mathrm{Y})$ indicate that the data obtained is reliable because the value of Cronbach's Alpha is 0.667 .

Normality test

Table 4.11. Normality Test Results

\begin{tabular}{lcccc}
\hline \multirow{2}{*}{ Test of Normality } & \multicolumn{3}{c}{ Kolmogrov-Smirnov } \\
\cline { 2 - 5 } & Sig. & & Cutt Off & Information \\
\hline Trust (X1) & 0,132 & $>$ & 0,05 & Normal \\
Product Quality (X2) & 0,124 & $>$ & 0,05 & Normal \\
Service Quality (X3) & 0,116 & $>$ & 0,05 & Normal \\
Purchase Decision (Y) & 0,145 & $>$ & 0,05 & Normal \\
\hline
\end{tabular}

Data Source: Processed from Questionnaire, 2019

than 0.05 , so that it can be stated that the data in this study are normally distributed. The normality test also aims to test whether in a regression model, the independent variable or

Based on Table 4.11, it can be seen that the both have a normal distribution or absolute good regression probability value or significance for each variable is greater is normal or near normal data distribution.



Data Source: Processed from Questionnaire, 2019

\section{Multicollinearity Test}

Figure 4.2. Normality Test Results

Table 4.12. Multicollinearity Test Results

\begin{tabular}{lcccc}
\hline Test of Multikolinierity & VIF & & Cutt Off & Information \\
\hline Trust (X1) & 1.229 & $<$ & 10 & Multicollinearity does not occur \\
Product Quality (X2) & 1.365 & $<$ & 10 & Multicollinearity does not occur \\
Service Quality (X3) & 1.174 & $<$ & 10 & Multicollinearity does not occur \\
\hline
\end{tabular}

Data Source: Processed from Questionnaire, 2019

Heterokedastisitas Test

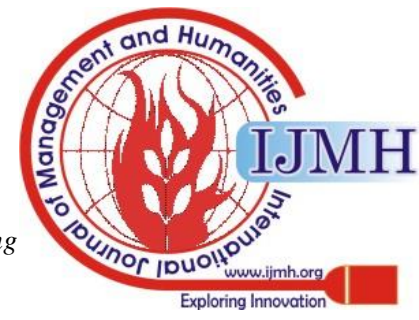




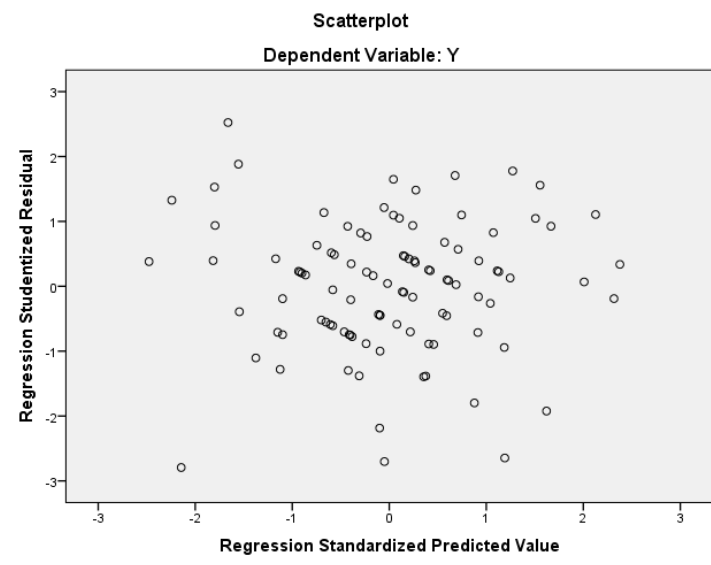

Data Source: Processed from Questionnaire, 2019

Figure 4.3.

Heteroscedasticity Test Results

$$
\begin{gathered}
Y=a+b_{1} X_{1}+b_{2} X_{2}+b_{3} X_{3} \\
Y=6.497+0,239 X_{1}+0,277 X_{2}+0,225 X_{3}
\end{gathered}
$$

From the linear regression equation above, it can be seen that the positive constant value of 6.497 shows that there is a positive influence between the independent variables of trust (X1) of 0.239 , there is a positive influence between the independent variables of product quality (X2) of 0.277 and there is a positive influence between the independent variables of quality service (X3) of 0.225 for the dependent variable of purchase decision (Y). Therefore, customers are strongly influenced by independent variables of trust, product quality and service quality (X). Besides that, there are other factors that also influence customer satisfaction but are not included in this study.

Feasibility Test Model (Test F)

\section{Analysis of Multiple Linear Regression}

\begin{tabular}{|c|c|c|c|c|c|c|}
\hline \multicolumn{7}{|c|}{ ANNOVA $^{b}$} \\
\hline Model & & $\begin{array}{l}\text { Sum of } \\
\text { Squares }\end{array}$ & Df & Mean Square & $\mathbf{F}$ & Sig. \\
\hline \multirow[t]{3}{*}{1} & Regression & 211.162 & 3 & 70.387 & 21.144 & $.000^{a}$ \\
\hline & Residual & 319.588 & 96 & 3.329 & & \\
\hline & Total & 530.750 & 99 & & & \\
\hline
\end{tabular}

Table 4.13. ANNOVA: Independent Variable Influence (X) Together on Dependent Variables (Y)

Unrestricted Variables: Trust, Product Quality and Service Quality Bound Variables: Purchase Decisions

Table 4.14. Regression Coefficient

\begin{tabular}{clccccc}
\hline \multirow{2}{*}{ Model } & & \multicolumn{2}{c}{$\begin{array}{c}\text { Coefficients } \\
\text { Unstandardized } \\
\text { Coefficients }\end{array}$} & $\begin{array}{c}\text { Standardized } \\
\text { Coefficients }\end{array}$ & t & Sig. \\
\hline $\mathbf{1}$ & & B & Std. Error & Beta & & \\
& (Constant) & 6.497 & 1.715 & & 3.789 & $\mathbf{0 , 0 0 0}$ \\
& Trust & 0,239 & 0,071 & 0,296 & 3.368 & $\mathbf{0 , 0 0 1}$ \\
& Product Quality & 0,277 & 0,087 & 0,293 & 3.162 & $\mathbf{0 , 0 0 2}$ \\
& Service Quality & 0,225 & 0,077 & 0,250 & 2.916 & $\mathbf{0 , 0 0 4}$ \\
Bound Variables: Purchase Decisions & & & & \\
\hline
\end{tabular}

Data Source: Processed from the Questionnaire

Based on the results of the t-test analysis calculation in Table 4.14, it can be described as follows:

1. Trust variable (X1), has a beta value of 0.239 with a significant value of 0.001 which is smaller than 0.05 . This means that the trust variable has a positive and significant influence on purchasing decisions.

2. Variable product quality (X2), has a beta of 0.277 with a significance value of 0.002 which is smaller than 0.05 . This means that product quality variables have a positive and significant influence on purchasing decisions.

3. Service quality variable (X3), has a beta of 0.225 with a significance value of 0.004 which is smaller than 0.05 . This means that service quality variables have a positive and significant influence on purchasing decisions.

\section{B. Discussion of Research Results}

\section{Effect of Trust (X1) on Purchasing Decisions (Y)}

- Trust has a positive and significant effect on purchasing decisions. From the results of the study obtained the coefficient for the trust variable of 0.239 with a significant value of 0.001 where this value is significant at the 0.05 significance level because it is smaller than 0.05 . Thus, that trust has a positive and significant effect on purchasing decisions. Based on the results of research and interviews with several respondents in the field, it was found that consumers already felt that consumers' trust in ecommerce Shopee was very good. 
Consumers feel that when shopping through ecommerce Shopee there is little chance of fraud by irresponsible sellers. Consumers also feel that shopping through Shopee e-commerce all transactions (chat or purchase) that are always supervised by Shopee which aims to avoid payment / transactions outside of Shopee. Based on the respondents' dominant data is the average age $>30$ years as many as 57 respondents and the minority respondents were female as many as 79 respondents. People who are consumers of Shopee feel that trust is the main key to making a purchase. If from the beginning the consumer does not believe in something, then the purchase will not occur. Image This excellent shopee among the public must be maintained so that consumers will always make purchase transactions at Shopee. In addition to this, Shopee must expressly give a warning to sellers who sell in Shopee in order to provide real and accurate information on products sold and can deliver products ordered by consumers on time. By providing accurate information and delivering goods on time, consumers will then make purchases and will have an impact on the satisfaction of the services provided by Shopee

\section{Pengaruh Kualitas Produk (X2) Terhadap Keputusan Pembelian (Y)}

$\mathrm{K}$ Trust has a positive and significant effect on purchasing decisions. From the results of the study obtained the coefficient for the trust variable of 0.239 with a significant value of 0.001 where this value is significant at the 0.05 significance level because it is smaller than 0.05 . Thus, that trust has a positive and significant effect on purchasing decisions. Based on the results of research and interviews with several respondents in the field, it was found that consumers already felt that consumers' trust in ecommerce Shopee was very good. Consumers feel that when shopping through e-commerce Shopee there is little chance of fraud by irresponsible sellers. Consumers also feel that shopping through Shopee e-commerce all transactions (chat or purchase) that are always supervised by Shopee which aims to avoid payment / transactions outside of Shopee.

Based on the respondents' dominant data is the average age $>30$ years as many as 57 respondents and the minority respondents were female as many as 79 respondents. People who are consumers of Shopee feel that trust is the main key to making a purchase. If from the beginning the consumer does not believe in something, then the purchase will not occur. Image This excellent shopee among the public must be maintained so that consumers will always make purchase transactions at Shopee. In addition to this, Shopee must expressly give a warning to sellers who sell in Shopee in order to provide real and accurate information on products sold and can deliver products ordered by consumers on time. By providing accurate information and delivering goods on time, consumers will then make purchases and will have an impact on the satisfaction of the services provided by Shopee.

\section{Effect of Service Quality (X3) on Purchasing Decisions} (Y)

Service quality has a positive and significant effect on purchasing decisions. From the results of the study obtained coefficients for service quality variables of 0.225 with a significant value of 0.004 where this value is significant at the 0.05 significance level because it is smaller than 0.05 . Thus, that service quality has a positive and significant effect on purchasing decisions. Based on the results of research and interviews with several respondents in the field, finding results that consumers feel the quality of service provided by e-commerce Shopee and seller at Shopee is very good. E-commerce Shopee and Shopee sellers have been very good in responding to consumer responses, complaints and questions about the products sold. The e-commerce Shopee has been very good at dealing with problems and responding to consumer complaints such as the refund process, the process of returning damaged items etc. Shopee also keeps an eye on all transactions made by sellers and buyers in making transactions. Consumers will feel safe when making purchases through Shopee with the quality of services that have been provided and responsive.

\section{CONCLUSIONS AND RECOMMENDATIONS}

\section{V.CONCLUSIONS}

1. Trust variables have a positive and significant effect on purchasing decisions at e-commerce Shopee in Palembang.

2. Product quality variables have a positive and significant effect on purchasing decisions at e-commerce Shopee in Palembang.

3. Service quality variables have a positive and significant effect on purchasing decisions at e-commerce Shopee in Palembang.

\section{RECOMMENDATIONS}

\section{For Shopee Parties}

a. The trust given by Shopee and the seller has been very good for consumers. But sellers (sellers) who sell must provide information about products that are sold in accordance with the actual quality and specifications. In addition, the seller (seller) also needs to improve the process of shipping products that have been ordered by consumers so they can be quickly used by consumers.

b. Product quality provided by the seller (seller) is good enough. But what needs to be improved is that the seller provides prices according to the quality of the product offered to cause consumers to buy. If the product offered is in accordance with the price and quality, then consumers will then make a decision to buy the product.

c. Service Quality provided by Shopee and Shopee sellers is very good, but needs to be improved to be able to quickly respond to chat, responses or even complaints from consumers so that consumers feel valued if the message they send is quick to reply.

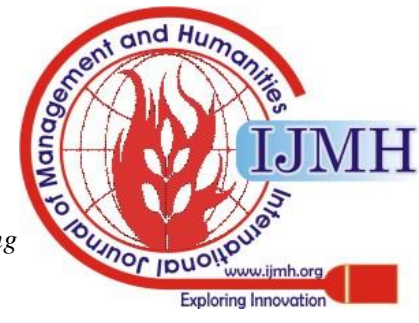




\section{REFFERENCE}

1. Danang, Sunyoto. 2013. Metodologi Penelitian Akuntansi. Bandung: PT. Refika Aditama Anggota Ikapi.

2. .Kotler dan Keller. 2012. Manajemen Pemasaran. Edisi 12. Jakarta: Erlangga.

3. Kotler, Philip, Amstrong, Gary. 2014. Prinsip-prinsip Manajemen. Edisi 14, Jilid 1. Jakarta: Erlangga.

4. Mudrajat Kuncoro. 2013. Manajemen Riset untuk Bisnis dan Ekonomi. Edisi 4. Jakarta: Erlangga.

5. Muhammad N., Dwi. 2018. Pengaruh Kepercayaan, Kualitas Informasi, dan

6. Sugiyono. 2012. Metode Penelitian Administrasi, Bandung: CV. Alfabeta.

7. Tjiptono, Fandy., Gregorius. 2012. Pemasaran Strategik. Yogyakarta: Andi. 